Sport Science: Jurnal Sain Olahraga dan Pendidikan Jasmani ISSN 114-562X (Cetak), ISSN XXXX-XXXX(Online)

http://sportscience.ppj.unp.ac.id/index.php/jss/index

\title{
Studi Pelaksanaan Proses Belajar Mengajar Pendidikan Jasmani Olahraga Kesehatan
}

\author{
Arie Prima Richi ${ }^{1}$, Arie Asnaldi ${ }^{2}$ \\ ${ }^{12}$ Fakultas Ilmu Keolahragaan, Universitas Negeri Padang, Indonesia. \\ E-mail: arierichi@yahoo.com¹, ishakaziz@,fik.unp.ac.id²,
}

\begin{abstract}
Abstrak
Berdasarkan observasi yang ditemukan masih banyak terdapat peserta didik yang tidak mengikuti pembelajaran penjasorkes dengan serius dan semangat. Penelitian ini merupakan penelitian deskriptif untuk mengetahui minat siswi terhadap pembelajaran penjas orkes di SDN 25 Air Tawar Selatan Padang, tujuan penelitian adalah bagaimana minat siswi terhadap pembelajaran penjas orkes di SDN 25 Air Tawar Selatan Padang.

Populasi dalam penelitian ini adalah siswi kelas IV sebanyak 16 orang dan siswi kelas V sebanyak 17 orang pada tahun ajaran 2009/2010 yang berjumlah 33 orang. Pengambilan data dilakukan dengan pengisian angket/kuesioner dan pengambilan sampel dilakukan dengan teknik random sampling yaitu setiap kelas dicari sampel 25\% dengan demikian jumlah sampel dalam penelitian ini sebanyak 33 orang.

Hasil penelitian menunjukkan bahwa minat siswi terhadap pembelajaran penjas orkes pada SDN 25 Air Tawar Selatan Padang dalam skor rata-rata 3,60. Dengan begitu dapat disimpulkan bahwa Studi Pelaksanaan Proses Belajar Mengajar Penjasorkes di SDN 25 Air Tawar Selatan Kota Padang adalah sedang. Diharapkan hasil penelitian ini berguna bagi pihak terkait agar lebih memperhatikan pelaksanaan pembelajaran penjasorkes dari segala unsur agar proses pembelajaran penjasorkes terlaksankan menurut semestinya.
\end{abstract}

Kata Kunci: Pendidikan Jasmani, Kesehatan, dan Rekreasi, Proses Belajar Mengaja

\begin{abstract}
Based on observations found there are still many students who do not take Physical Education learning seriously and with enthusiasm. This research is a descriptive study to find out the students 'interest in the learning of physical education orchestra in SDN 25 Air Tawar Selatan Padang, the purpose of this research is how the students' interest in learning about physical education orchestra in SDN 25 Air Tawar Selatan Padang.

The population in this study were 16 class IV students and 17 class V students of 17 students in the 2009/2010 school year, totaling 33 people. Data collection was carried out by filling out a questionnaire / questionnaire and sampling was done by random sampling technique that each class sought a sample of $25 \%$ so the number of samples in this study were 33 people.

The results showed that the students' interest in learning about physical education orchestra at SDN 25 Air Tawar Selatan Padang in an average score of 3.60. Thus it can be concluded that the Study of the Implementation of Teaching and Learning Process of Physical Education at SDN 25 Air Tawar Selatan, Padang City is moderate. It is hoped that the results of this study will be useful for related parties to pay more attention to the implementation of the learning of Physical Education of all elements so that the learning process of Physical Education is carried out accordingly.
\end{abstract}


Keywords: Physical Education, Health, and Recreation, Teaching and Learning Process

\section{PENDAHULUAN}

Semua olahraga yang ada dalam kurikulum Sekolah Dasar Negeri 25 Air Tawar Selatan Kota Padang mempunyai fungsi yang sama yaitu untuk meningkatkan kesegaran jasmani peserta didik kegiatan pembelajaran penjas orkes tersebut dapat dilakukan secara beregu atau perorangan di sekolah maupun diluar sekolah. Sesuai dengan tujuan penjas orkes jelaslah betapa pentingnya mata pelajaran Penjas Orkes di Sekolah Menengah Atas Negeri seluruh Indonesia. Dengan adanya Penjas Orkes yang sehat mempunyai keterampilan gerak dasar yang benar, manusia Indonesia yang disiplin serta beriman dan bertakwa kepada Tuhan Yang Maha Esa.

Sama dengan sekolah lainnya mata pelajaran penjas orkes juga diajarkan di sekolah ini mulai dari kelas III, IV, V dan VI, berdasarkan kurikulum KTSP Sekolah Dasar Negeri 25 Air Tawar Selatan Kota Padang jenis - jenis kegiatan yang diajarkan dalam penjas orkes yaitu kegiatan atletik (lari 800 dan $1500 \mathrm{M}$, lompat jauh, lompat tinggi), latihan kebugaran jasmani, gerak ritmik, permainan bola besar diantaranya (bola basket, bola voli), bela diri seperti (karate, silat, judo dan lain-lain) dan renang.

Hal ini memegang peranan penting agar peserta didik dapat bergerak dan memperoleh kesegaran jasmani. Ditinjau dari pelaksanaan pengajaran penjas orkes sudah seharusnya berjalan dengan baik dapat mencapai tujuan penjas orkes secara optimal mengingat banyak faktor yang mempengaruhi keberhasilan peserta didik dalam belajar diantaranya perencanaan pengajaran, motivasi peserta didik, sarana dan prasarana, lingkungan, pelaksanaan materi yang diajarkan, dukungan sekolah, dukungan orang tua untuk menumbuhkannya, dengan demikian diharapkan dapat membantu kelancaran peserta didik dalam mengikuti pembelanjaran penjas.

Perbedaan atau kesenjangan antara apa yang kita percayai dan apa yang kita praktikkan (gap antara teori dan praktek) adalah sebuah duri dalam bidang pendidikan jasmani kita. Penjas orkes merupakan bagian integral dari sistem pendidikan nasional.

"Penjas orkes adalah suatu tahap atas aspek dari proses pendidikan keseluruhan yang berkenan dengan pengembangan dan penggunaan kemampuan gerak individu yang dilakukan atas kemampuan sendiri serta bermanfaat dan dengan reaksi dan respon yang terkait langsung dengan mental, emosi dan sosial "(Nixon $2004: 14)$

Pembelajaran penjas orkes pada hakikatnya merupakan suatu proses interaksi antara siswa, guru dan lingkungannya dalam mencapai suatu tujuan yang telah ditetapkan. Tugas guru adalah mengajar dan mendidik serta mengkoordinasikan lingkungan agar dapat mencapai perubahan prilaku siswa kearah yang lebih baik, dalam proses pembelajaran guru penjas orkes harus merencanakan suatu program pengajaran.

Namun ini tidak berjalan jika tidak adanya perencanaan pengajaran yang matang yang akan diajarkan oleh guru penjas orkes. Serta didukung oleh sarana dan prasarana sebagai penunjang dalam pembelajaran pendidikan jasmani di Sekolah Dasar Negeri 25 Air Tawar Selatan Kota Padang. Guru penjas orkes di Sekolah Dasar Negeri 25 Air Tawar Selatan Kota Padang ini terdiri dari 2 orang yang berstatus honor, jumlah kelas 6 lokal, terdiri dari kelas 10 jumlah 2 lokal, kelas 11 jumlah 2 lokal, ke1as 12 jumlah 2 lokal.

Dilihat dari sarana dan prasarana yang akan mendukung agar terlaksananya tujuan pendidikan jasmani pada Sekolah Dasar Negeri 25 Air Tawar Selatan Kota Padang sudah dilengkapi dengan adanya 6 buah bola voli , 6 buah bola basket, 1 matras, 2 net (1 net voli dan 1 net bulu tangkis). Disisi lain suksesnya proses belajar mengajar penjas orkes juga didukung oleh : peranan orang tua (dukungan), suasana lingkungan, dan peran aktif guru di lapangan, Serta minat peserta didik dalam proses belajar mengajar.

Minat mempunyai pengaruh yang lebih besar terhadap hasil belajar di bandingkan dengan 
faktor lain. Untuk minat dan rasa percaya diri peserta didik merupakan hal yang paling penting untuk mencapai hasil belajar yang lebih baik perlu di perhatikan. Kemampuan peserta didik dalam melakukan kegiatan pembelajaran penjas orkes akan terlihat dari kemampuan motorik yang di tampilkan peserta didik yang bersangkutan. Penjas orkes merupakan salah satu mata pelajaran yang tercantum dalam pendidikan kurikulum pendidikan nasional, mata pelajaran ini bertujuan untuk meningkatkan kesegaran jasmani agar mampu hidup secara baik di tengah masyarakat selain memiliki skill dalam bidang olahraga, Dalam pembelajaran siswi berperan secara aktif dalam setiap kegiatan selama proses belajar mengajar berlangsung.

\section{METODE}

Jenis dari penelitian ini adalah berbentuk deskriptif yang bertujuan untuk memberikan pengertian dan penginterprestasikan data sebagaimana semestinya. Penelitian deskriptif dalam penelitian ini yang bermaksud adalah untuk melihat minat peserta didik Sekolah Dasar Negeri 25 Air Tawar Selatan Kota Padang terhadap pembelajaran penjas orkes.

Lufri dan Ardi (1999:71) menjelaskan bahwa penelitian deskriptif adalah.;

"Penelitian yang dilakukan terhadap kejadian yang sedang atau sudah terjadi. Rancangan ini dilakukan melalui beberapa prosedur untuk menentukan populasi, sampel, membuat angket dan menyebarkan kepada sampel kemudian data diperoleh diolah dengan menggunakan teknik deskriptik"

Penelitian ini dilaksanakan di Sekolah Dasar Negeri 25 Air Tawar Selatan Kota Padang pada saat semester genap tahun ajaran 2009/2010 atau setelah proposal ini disetujui oleh dosen pembimbing dan dosen penguji.

Berdasarkan observasi yang diterima penulis dari wakil kepala sekolah dan tata usaha di Sekolah Dasar Negeri 25 Air Tawar Selatan Kota Padang, bahwa jumlah peserta didik kelas III dan IV sebagai 60 orang dan peserta didik kelas IV sebanyak 36 orang. Jadi jumlah populasi dalam penelitian ini sebanyak 96 orang, peserta didik kelas VI sengaja tidak diambil sebagai populasi karena mereka sedang mempersiapkan diri untuk menghadapi UAN (ujian akhir nasional). Untuk lebih jelas jumlah peserta didik yang mengambil mata pelajaran penjas orkes yang masih terdaftar pada semester genap dapat dilihat pada label di bawah ini

\section{Tabel 1}

\section{Populasi peserta didik kelas III Sampai V Sekolah Dasar Negeri 25 Air Tawar Selatan Kota} Padang

\begin{tabular}{|c|c|c|}
\hline No & Kelas & Populasi \\
\hline 1 & I & 27 \\
2 & II & 30 \\
3 & III & 32 \\
4 & IV & 33 \\
5 & V & 35 \\
6 & VI & 29 \\
\multicolumn{2}{|c|}{ Jumlah } & 186 \\
\hline
\end{tabular}

Sumber: Tata Usaha Sekolah Dasar Negeri 25 Air Tawar Selatan Kota Padang tahun ajaran 2009/20010.

Mengingat jumlah populasi (cukup besar) juga keterbatasan waktu, biaya dan tenaga yang dimiliki, maka penelitian ini tidak dilakukan terhadap keseluruhan populasi tetapi hanya dilakukan terhadap sampel saja. Menurut Sudjana (1989:160) mengemukakan sampel adalah "sebagian yang 
diambil dari populasi sedangkan penarikan sampel dalam penelitian ini dilakukan secara proposional random sampling".

Dalam penelitian ini sebanyak jumlah sampel adalah 33 orang diambil sebanyak $30 \%$ dari jumlah populasi untuk lebih jelasnya dalam dapat dilihat pada tabel dibawah ini. Sedangkan kelas III dalam Studi Pelaksanaan PBM Penjasorkes di SDN 25 Air Tawar Kota Padang tidak diikukan karena kemampuan peserta didik dalam mengisi angket penelitian.

Tabel 2

\section{Distribusi sampel peserta didik kelas III samapai Kelas V Sekolah Dasar Negeri 25 Air Tawar} Selatan Kota Padang

\begin{tabular}{|c|c|c|}
\hline No & Kelas & Sampel \\
\hline 1 & IV & 16 \\
2 & V & 17 \\
\multicolumn{2}{|c|}{ Jumlah } & 33 \\
\hline
\end{tabular}

Data pada penelitian diperoleh dengan menggunakan cara observasi, wawancara dan quesioner atau dengan penyebaran angket. Langkah-langkah yang dilakukan dalam pembuatan angket yaitu terlebih dahulu membuat kisi-kisi pertanyaan berdasarkan indikator-indikator dari variabel, kemudian barulah pertanyaan-pertanyaan tersebut disusun untuk dijadikan sebagai angket. Jenis angket yang digunakan adalah angket tertutup, dimana responden diberikan alternatif jawaban dan diminta untuk memilih jawaban yang telah tersedia.

Skala pengukuran yang digunakan adalah skala Guttman dengan dua alternatif jawaban, "ya" dan"tidak". Berdasarkan kutipan dari Suwirman (2004:79) bahwa skala "Guttman" adalah skala yang digunakan untuk jawaban yang bersifat jelas/tegas dan konsisten. Untuk jawaban 'ya' diberi skor "1", sedangkan jawaban 'tidak'mendapatkan skor"0". Skor belajar siswa yang berupa kualifikasikan sebagai berikut:

$$
\begin{aligned}
& 81 \%-100 \%=\text { Sangat Tinggi } \\
& 61 \%-80 \%=\text { Tinggi } \\
& 41 \%-60 \%=\text { Sedang } \\
& 21 \%-40 \%=\text { Rendah } \\
& 0 \%-20 \%=\text { Sangat Rendah } \\
& \text { (Arikunto } 1998: 57 \text { ) }
\end{aligned}
$$

Setelah angket disebarkan dan dikumpulkan selanjutnya dilakukan pengolahan data berdasarkan angket yang terkumpul dan telah memenuhi syarat yang dianalisa. teknik analisis data dilakukan dengan menggunakan statisitik kooperatatif yang menggunakan stastika kooperatif yang menggunakan kabulasi frekuensi rumus sebagai berikut:

$$
P: \frac{f}{N} x 100 \%
$$

\section{HASIL DAN PEMBAHASAN (70\%) \\ Hasil Penelitian}

Pada bagian ini akan dilakukan analisis terhadap hasil penelitian. Sesuai dengan pertanyaan penelitian yang diajukan, sebelum dilakukan analisis terhadap data tersebut tentang "Pelaksanaan Proses Belajar Mengajar Praktek Pendidikan Jasmani Olahraga Kesehatan di SDN 25 Air Tawar Selatan Kota Padang" yang ditinjau dari aspek minat peserta didik dan modifikasi sarana prasarana, maka dilakukan verifikasi (seleksi) terhadap data yang diperoleh.

Tujuan dilakukan verifikasi data adalah apabila ada data yang tidak lengkap yang di isi oleh responden dalam instrumen, maka data tersebut tidak dapat diolah. Kriteria lengkapnya data yang di 


\section{Sport Science: Jurnal Sain Olahraga dan Pendidikan Jasmani}

ISSN 114-562X (Cetak), ISSN XXXX-XXXX(Online)

http://sportscience.ppj.unp.ac.id/index.php/jss/index

isi responden terhadap instrumen, apabila seluruh pertanyaan dijawab sesuai dengan instruksi yang ada dalam instrumentasi tersebut. Berdasarkan hasil verifikasi terhadap data yang diberikan, ternyata semua dapat diolah.

\section{Deskripsi dan Analisa Data}

Data yang terkumpul berupa skor dimana setiap item yang telah dijawab diberi bobot 1 dan 0 . skor tersebut merupakan data hasil penelitian. Dari hasil pengolahan data, dapat dideskripsikan data sebagai berikut: Secara umum Pelaksanaan Proses Belajar Mengajar Pendidikan Jasmani Olahraga Kesehatan di Sekolah Dasar Negeri 25 Air Tawar Selatan Kota Padang termasuk kedalam kriteria sedang.

1. Persentase dan kriteria dalam Pelaksanaan Proses Belajar Mengajar Pendidikan Jasmani Olahraga Kesehatan di Sekolah Dasar Negeri 25 Air Tawar Selatan Kota Padang dilihat dari masing-masing sub variabel seperti pada tabel 3 .

Tabel 3

Persentase Berdasarkan Sub Variabel Studi Pelaksanaan Proses Belajar Mengajar Praktek Pendidikan Jasmani Olahraga Kesehatan di SDN 25 Air Tawar Selatan Kota Padang

\begin{tabular}{|c|l|c|}
\hline No & \multicolumn{1}{|c|}{ Sub Variabel } & Persentase \\
\hline 1 & Minat Peserta Didik & 60 \\
2 & Modifikasi Sarana dan prasarana & 40 \\
\hline
\end{tabular}

Berdasarkan tabel 3 dan grafik diatas, terlihat bahwa pelaksanaan proses belajar mengajar praktek pendidikan jasmani olahraga kesehatan ditinjau dari sub variabel maka dapat diketahui bahwa faktor motivasi peserta didik memiliki persentase tinggi diperoleh $60 \%$, dengan presentase 12 pertanyaan dengan sebagai penyebab hambatan dalam pelaksanaan pembelajaran pendidikan jasmani olahraga kesehatan, sedangkan modifikasi sarana dan prasarana memiliki persentase sedang diperoleh $40 \%$ dengan persentase 8 pertanyaan sebagai penyebab hambatan belajar bagi peserta didik. Selain dari tabel diatas, pelaksanaan proses belajar mengajar praktek pendidikan jasmani olahraga kesehatan di SDN 25 Air Tawar Selatan Kota Padang dapat juga dilihat pada grafik di bawah ini:

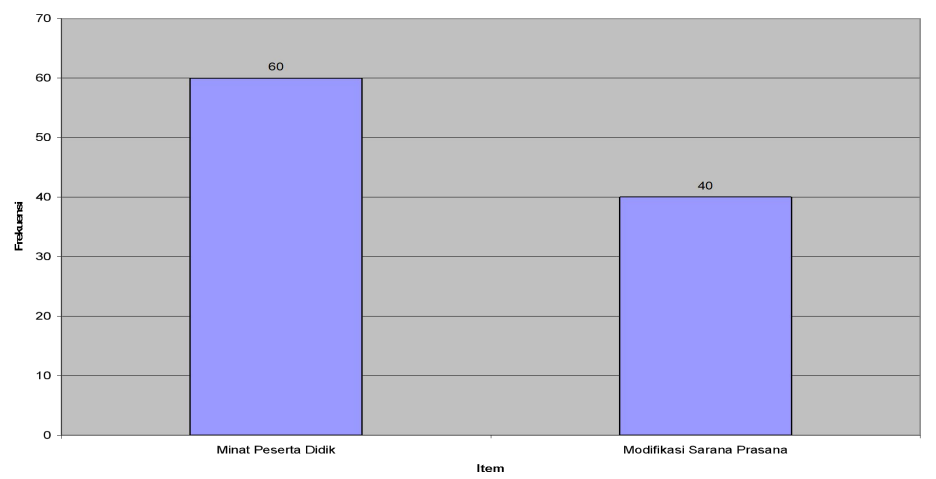

Gambar 2. Grafik Persentase Sub Variabel Studi Pelaksanaan PBM Penjasorkes di SDN 25 Air Tawar Selatan Kota Padang

2. Persentase dan kriteria pelaksanaan proses belajar mengajar praktek pendidikan jasmani olahraga kesehatan di SDN 25 Air Tawar Selatan Kota Padang Kota Padang dilihat dari masing-masing indikator dapat dilihat pada tabel 4.

Tabel 4

Persentase Berdasarkan Indikator Keseluruhan Studi Pelaksanaan Proses Belajar Mengajar

Pendidikan Jasmani, Olahraga dan Kesehatan

di SDN 25 Air Tawar Selatan Kota Padang

Studi Pelaksanaan Proses Belajar Mengajar Pendidikan Jasmani Olahraga

Kesehatan 


\begin{tabular}{|l|l|c|c|c|c|}
\hline \multirow{2}{*}{ No } & \multirow{2}{*}{ Sub Variabel/Indikator } & \multicolumn{2}{|c|}{ Persentase } & \multicolumn{2}{c|}{ Kriteria } \\
\cline { 3 - 6 } & & Ya & Tidak & Ya & Tidak \\
\hline $1 \quad$ & Minat Peserta Didik & 60.71 & 39.29 & Tinggi & Rendah \\
& $\begin{array}{l}\text { • Interen } \\
\text { • Eksteren }\end{array}$ & 50.00 & 50.00 & Sedang & Sedang \\
& $\begin{array}{l}\text { Modifikasi Sarana dan prasara } \\
\text { • Peralatan Olahraga }\end{array}$ & 50,78 & 49.22 & Sedang & Sedang \\
& & & & & \\
\hline
\end{tabular}

Berdasarkan tabel 4 diatas pada indikato motivasi Peserta didik dapat dilihat bahwa Pelaksanaan Proses Belajar Mengajar Praktek Pendidikan Jasmani Olahraga dan Kesehatan untuk indikator motivasi instriksik memiliki kriteria Tinggi dengan presentase $60.71 \%$ dan frekuensi 136 pertanyaan pada jawaban IYA sedangkan pada jawaban TIDAK kriteria rendah dengan presentase $39.29 \%$ dan frekuensi 88 pertanyaan.

Selanjutnya pada indikator motivasi ekstrinsik memiliki kriteria sedang dengan presentase $50.00 \%$ dan frekuensi 80 pertanyaan pada jawaban IYA dan persetase ini sama dengan jawaban TIDAK dengan kriteria sedang dengan presentase sedang $50.00 \%$ dan frekuensi 80 pertanya. Dapat juga dilihat pada grafik dibawah ini;

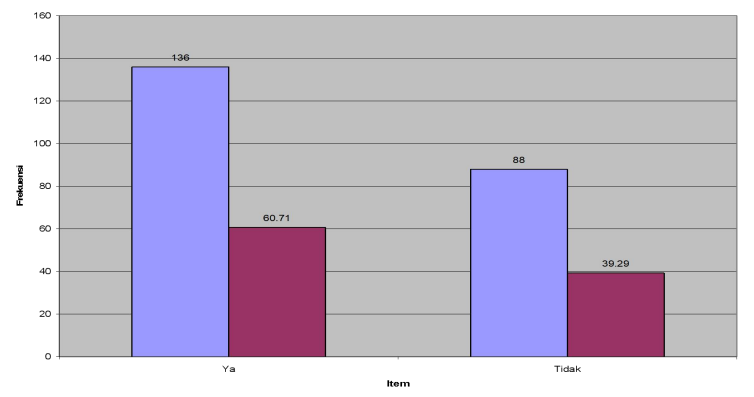

Gambar 3 ; Grafik Persentase Indikator Motivasi Peserta Didik

Pelaksanaan PBM Penjasorkes di SDN 25 Air Tawar Selatan Kota Padang

Sedangkan berdasarkan tabel 4 pada item 2 sub variabel modifikasi sarana prasarana pada indikator peralatan olahraga bahwa pelaksanaan proses belajar mengajar penjasorkes memiliki persentase sedang dengan presentase $50.78 \%$ dan frekuensi 130 pertanyaan yang menjawab IYA dan persentase sedang dengan presentase $49.22 \%$ dan frekuensi 126 pertanyaan yang menjawab TIDAK. Dapat juga dilihat pada grafik dibawah ini;

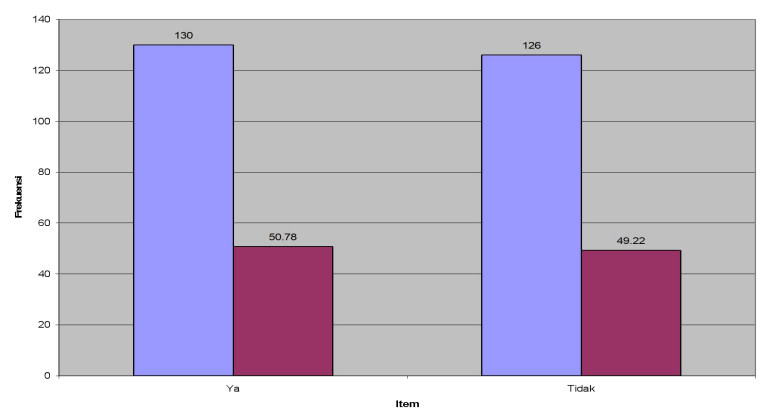

Gambar 4. Grarik Persentase Indikator Peralatan Olahraga Studi Pelaksanaan PBM Penjasorkes di SDN 25 Air Tawar Selatan Kota Padang 
Sport Science: Jurnal Sain Olahraga dan Pendidikan Jasmani

ISSN 114-562X (Cetak), ISSN XXXX-XXXX(Online)

http://sportscience.ppj.unp.ac.id/index.php/jss/index

Berdasarkan penelitian yang penulis lakukan, disimpulkan bahwa motivasi peserta didik dan modifikasi sarana prasarana memberikan pengaruh cukup sebagai penyebab hambatan belajar bagi peserta didik.

\section{Pembahasan}

Kecendrungan individu terhadap sesuatu terlihat dari minatnya. "Bila seseorang berminat terhadap suatu objek, maka orang tersebut akan memutuskan tenaga psikisnya yang tertuju pada objek. Minat penentu sukses atau gagalya kegiatan seseorang, minat yang besar akan mendorong motivasinya untuk belajar dan kurang minat akan menyebabkan kurangnya perhatian, sehingga menghambat pembelajaran.

Maka dapat disimpulkan bahwa jika seseorang berminat terhadap sesuatu, maka ia akan mempunyai keinginan terhadap yang diaminiatinya, memusatkan tenaga dan pikirannya. Seseorang yang beminat terhadap sesuatu tidak dapat dihalangi oleh orang lain, ia akan berusaha untuk mendapatkannya. Dalam psikologi umum dijelaskan bahwa minat itu adalah kesadaran seseorang pada suatu objek. Suatu masalah atau situasi yang mengandung sangkut paut terhadap dirinya.

Minat akan menjadi pendorong atau kemampuan bagi seseorang untuk melakukan perbuatan atau tindakan tertentu yang dianggapnya ada sangkut pautnya dengan diri seseorang. Minat seseorang terhadap suatu objek akan kelihatan melalui cara seseorang bertindak, memperhatikan dan melakukan kegiatan yang berhubungan dengan objek tersebut.

Sedangkan yang memiliki minat tinggi mempunyai karakteristik sebagai berikut: cepat menanggapi suatu masalah partisipasinya dan aktifitas tinggi, sesuatu yang menarik dipandang dan aktifitas serta oleh kekuatan psikis. Faktor-faktor yang mempengaruhi belajar pada prinsipnya akan dapat menjadi sumber faktor kesulitan. Hal ini dimungkingkan karena dalam faktor tersebut hal positif tidak menjadi masalah, akan tetapi jika pengaruh faktor tersebut hal negatif untuk belajar, maka dia akan menjadi dalam kesulitan dalam belajar.

Dari hasil penelitian dan pengamatan yang dilakukan peneliti bahwa pelaksanaan pembelajaran penjasorkes dalam motivasi instriksik diperoleh rata-rata variabel pada jawaban IYA adalah 84.47\%. Ini berarti motivasi instrisik tergolong sedang di SDN 25 Air Tawar Selatan Kota Padang Kota Padang. Selanjutnya rata-rata variabel pada jawaban TIDAK pada sub variabel motivasi peserta didik dalam motivasi instrisik dan ekstrinsik adalah $28.47 \%$. Ini berarti motivasi peserta didik tergolong kriteria rendah.

Dalam pengamatan ini minat siswa terhadap pembelajaran penjas orkes dibedakan atas 2 bagian, yaitu yang berminat rendah atau yang berminat tinggi. Memiliki minat rendah mempunyai karakteristik sebagai berikut: lambat menanggapi masalah yang kurang disenangi, partisipasi dan aktifitas kurang tinggi, suatu yang kurang menarik tidak mempunyai nilai yang berarti bagi dirinya, tidak membiasakan diri mengkaji suatu hal yang menarik, dan kreaktifitas tidak disertai oleh tenaga psikis. Sarana dan prasarana dalam kegiatan olahraga merupakan salah satu aspek penunjang yang sangat penting, baik dalam melakukan latihan maupun dalam proses belajar mengajar.

Dalam proses pengajaran olahraga, sarana dan prasarana berkaitan erat dengan kelangsungan dan kelancaran pelaksanaan pelajaran pendidikan jasmani. Di samping itu agar tujuan tercapai dengan baik, maka sarana dan prasarana yang digunakan harus sesuai dengan materi pelajaran yang layak pakai. Peralatan olahraga menjadi indikator persentase sedang sehingga memberikan pengaruh terhadap proses pembelajaran pendidikan jasmani. Hal ini bearti bahwa peralatan olahraga menunjukkan pengaruh yang cukup kuat sebagai penyebab hambatan dalam pembelajaran pendidikan jasmani olahraga dan kesehatan.

Dari hasil pengamatan peneliti di SDN 25 Air Tawar Selatan Kota Padang, peralatan olahraga yang ada sangat kurang dan sudah banyak yang rusak. Salah satu penyebab kerusakan alat pelajaran adalah jumlah peralatan yang sedikit dan tidak seimbangnya jumlah murid dengan peralatan olahraga. 
Dalam hal ini sangat dituntut kreatifitas guru untuk menciptakan peralatan olahraga/alat pelajaran tiruan yang disebut dengan simulator yang khusus dibuat untuk berlatih. Peralatan olahraga tiruan yang dimaksud adalah segala macam alat- alat yang dapat menunjang tercapainya kegiatan belajar mengajar dan menyebabkan tujuan pembelajaran dapat tercapai dengan baik. Peralatan olahraga/alat pelajaran tiruan diciptakan sendiri oleh guru mata pelajaran sehingga peserta didik tertarik untuk mengikuti pembelajaran pendidikan jasmani, olahraga dan kesehatan. Tanpa peralatan olahraga/alat pelajaran, kegiatan pembelajaran pendidikan jasmani, olahraga dan kesehatan tidak dapat berjalan dengan baik maka diperoleh rata-rata variabel untuk modifikasi sarana prasana indikator alat olahraga adalah $28.52 \%$.

Dari penjelasan diatas dapat dikatakan bahwa sarana dan prasarana penjasorkes sangat penting. Sarana dan prasarana penjasorkes yang tepat sangat membantu peserta didik untuk mengembangkan kebutuhannya karena kegiatan jasmani yang diajarkan guru harus disesuaikan dengan peralatan yang ada sehingga peserta didik memiliki keluasaan dalam melakukan aktifitas olahraga serta menyenangi kegiatan yang dilakukannya, dengan demikian kebutuhan anak didik akan media pembelajaran tercapai sesuai dengan tingkat kebutuhan dan perkembangan.

Pendidikan jasmani yang diajarkan disekolah dasar akan berhasil baik apabila proses belajar sesuai dengan tuntunan kurikulum yang berlaku, untuk itu harus didukung oleh sarana dan prasarana yang memadai. Bila sarana dan prasarana tidak memadai maka proses belajar mengajar tidak akan dapat dikembangkan secara optimal. Kurangnya sarana dan prasarana menyebabkan hambatan peserta didik terhadap mata pelajaran praktek pendidikan jasmani sehingga tujuan yang hendak dicapai kurang terlaksana sebagai mana mestinya.

Dengan kenyataan seperti itu, tentu proses pembelajaran jasmani disekolah tersebut kurang terlaksana dengan baik bahkan hampir untuk semua cabang olahraga permainan yang membutuhkan sarana belajar (bermain) tidak memenuhi persyaratan sesuai dengan peraturan yang ada. Selama ini pula proses pembelajaran praktek pendidikan jasmani kurang terlaksana sebagai mestinya.

\section{KESIMPULAN}

Berdasarkan hasil penelitian indikator-indikator tentang pengetahuan, pemahaman, sikap dan keinginan peserta didik dalam pembelajaran penjas orkes dapat disimpulkan bahwa minat peserta didik terhadap pembelajaran penjas orkes pada SDN 25 Air Tawar Selatan Kota Padang ternyata tergolong baik yang dibuktikan dengan skor persentase rata-rata variable keseluruhan $54.06 \%$ walaupun pada pemahaman dilapangan terdapat kendala-kendala seperti jadwal pembelajaran penjas orkes diadakan diluar jam pelajaran, lokasinya juga tidak bersih dari lingkungan sekolah, akan tetapi minat peserta didik SDN 25 Air Tawar Selatan Kota Padang terhadap pelajaran penjas orkes tetap bagus yang dibuktikan dengan persentase yang tinggi yang diperoleh dari hasil penelitian beberapa indikator.

Berdasarkan kesimpulan maka saran yang di berikan dalam penelitian ini, dengan diketahuinya minat peserta didik yang baik diharapkan peserta didik dapat mempertahankan dan meningkatkan minatnya dimasa yang akan datang, bagi guru merupakan sebagai bahan masukan untuk lebih dapat meningkatkan minat dalam pembelajaran penjas orkes, dan Bagi pihak sekolah dan orang tua Iebih memahami bahwa dalam proses pembelajaran penjas orkes didukung oleh minat yang dimiliki peserta didik.

\section{DAFTAR RUJUKAN}

Alnedral.1991.Pengaruh Metode Belajar dan Minat Mahasiswa Terhadap Prestasi Belajar Bola voli ('esis), Padang: FPOK IKIP

Elida,Prayitno. 1995. Rujukan Psikologi Pendidikan, Jakarta: Bharata Karya 
Sport Science: Jurnal Sain Olahraga dan Pendidikan Jasmani ISSN 114-562X (Cetak), ISSN XXXX-XXXX(Online)

http://sportscience.ppj.unp.ac.id/index.php/jss/index

Hamailik. 2003. Kurikulum dan pembelajaran, Jakarta : bumi aksara

Leok.Mono jt.Lobby. 1992 Belajar Bagaimana Belajar, Jakarta: Gunung Mulia

Lufri and Ardi (1999). Metodologi Penelitian. FMIP A UNP Padang

Nixon J.E danjaret AR.2004. AN introduction to physical education philia dhelphi sounder college

Sadirmau.lvse. Motivasi Belajar dan instruksional, Jakarta: Rajawali pers

Sudjana.1989. Metodologi Statistik: Bandung: Bung Transito

Suharsimi, Arikunto. 1989. Manajemen pendidikan, Jogjakarta: Rineka cipta

Suharsimi, Arikunto. 1998. Organisasi dan administrasi pendidikan dan teknologi dan kejuruan. Depdikbud: Jakarta

Suryo, Subroto. 2006. Proses belajar mengajar di sekolah; Jogjakarta : Rineka cipta

Undang-Undang RI No 3 tahun 2003 tentang Sistim Keolahragaan Nasional

Undang-Undang Republik Indonesia NO 20 Tahun 2003 Tentang Sistem Pendidikan Nasional, 2003 Jakarta 